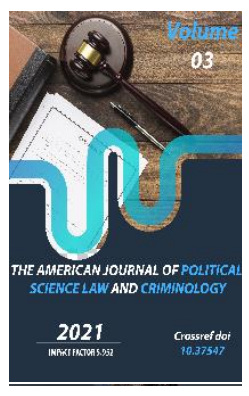

\title{
Legal System Of Karakalpakstan In The Republic Of Uzbekistan: Nature And Key Elements
}

\author{
Aytmuratov Rinat Baxitovich \\ Head of The Reception Office Of The Prime Minister Of The Republic Of Uzbekistan For \\ Consideration of Appeals Of Entrepreneurs In The Republic Of Karakalpakstan
}

Journal Website: http://usajournalshub.c om/index,php/tajpslc

Copyright: Original content from this work may be used under the terms of the creative commons attributes 4.0 licence.

\section{ABSTRACT}

The article describes the legal system of Karakalpakstan, its generally recognized needs and interests of people, as well as the logical interdependence of legal events, tools, processes, institutions, institutions, taking into account a free life and a prosperous future of citizens.

\section{KEYWORDS}

National legal system, state sovereignty, regulatory documents.

\section{INTRODUCTION}

The national legal system takes into account advanced ideas, traditions, cultural and moral characteristics of society in the process of political, economic, historical and cultural development of the country. Since
Karakalpakstan is a sovereign democratic republic within the Republic of Uzbekistan, the legal system of Karakalpakstan, like the legal system of the Republic of Uzbekistan, was created taking into account the generally 
recognized needs and interests of the people, as well as a free life and a prosperous future. of our citizens., is a logically related expression of institutions.

The proclamation of the state sovereignty of the Republic of Uzbekistan, the choice of market economy, political and ideological pluralism open a wide range of opportunities for the legal system of Uzbekistan to get closer to the family of Romano-German law both in form and content.

It is known that the family of law means a more or less complex set of national legal systems, based on the similarity of historical formations within a single legal boundary, the structure of sources of law, leading branches of law and legal institutions, law enforcement. common aspects of legal science 1 .

According to prominent lawyers A. Saidov and V. Tajikkhanov, the current legal system of Uzbekistan can be attributed to the family of Romano-German legal systems in the following basic aspects:

First, the Republic of Uzbekistan is a codified country. The main source of law is the legal acts adopted by the highest authorities of the state. The main branches of law in our country have been codified;

Secondly, a strict hierarchy of sources of law. The system of sources of law in Uzbekistan includes the Constitution, constitutional laws, ordinary laws, presidential decrees, Cabinet decrees, regulations of central and local governments;

\footnotetext{
1 Давлат ва хуқуқ назарияси: Дарслик. / Масъул мухаррирлар Х.Б.Бобоев ва Х.Т.Одилқориев. Тошкент: Иқтисодиёт ва хуқуқ дунёси, 2000. - Б. 387.
}

Thirdly, the rule of law is an important component of the hierarchy of this system of sources of law. The rule of the Constitution plays an important role in this. It prohibits any activity that is contrary to the Constitution, as well as legislative activity, the basic norm of constitutional norms in relation to traditional criteria, i.e. the interpretation and application of laws, the duty of all law enforcement bodies to act in accordance with the drafting. constitutional norms. the specific nature and complex procedure of constitutional control implies special protection of the Constitution, i.e. the existence of constitutional control;

Fourthly, the basic principles governing the organization of justice and the judicial system ${ }^{2}$.

The main criteria of the rule of law in Uzbekistan are the separation of powers, the rule of human rights and freedoms, the rule of the Constitution and laws, constitutional control and others. These principles are an important factor in bringing Uzbekistan's legal system closer to the family of Roman-German law. Uzbekistan thus now has a system of sources of law and legal systems typical of the Roman-German legal family. This in itself means that the legal system of Karakalpakstan belongs to the family of Romano-German law.

As stated in the Constitution of the Republic of Uzbekistan, the Republic of Karakalpakstan adopts its Constitution. Thus, the following constitutional and legal system operates in the Republic of Karakalpakstan:

Constitution of the Republic of Karakalpakstan;

\footnotetext{
2 Саидов А., Тожихонов У. Давлат ва хуқуқ назарияси. Икки жилдли. 2-жилд. Хуқуқ назарияси. - Тошкент: Адолат, 2001. - Б. 484.
} 
Constitutional laws of the Republic of Karakalpakstan;

Regulatory acts (acts) of the Republic of Karakalpakstan are adopted on the basis of laws to address issues of exclusive competence.

The constitutional and legal system of the Republic of Karakalpakstan is an integral part of the constitutional and legal system of the Republic of Uzbekistan. The commonality and indivisibility of the legal system of the Republic of Uzbekistan imposes certain requirements on the constitutional and legal system of the Republic of Karakalpakstan. They are:

- The Constitution of the Republic of Karakalpakstan cannot be contrary to the Constitution of the Republic of Uzbekistan;

- The laws of the Republic of Uzbekistan are also mandatory in the territory of the Republic of Karakalpakstan ${ }^{3}$.

"One of the most important characteristics of a democratic state based on the rule of law is the equality of all citizens before the law, the rule of law and the rule of law. The rule of the Constitution and the law mean, first, the strict rule of law in all areas of public life, no one, no public body, official or any other citizen can be exempt from the obligation to obey the law, and secondly, the Constitution and the rule of law and means that political relations can only be governed by law.

Article 15 of the Constitution provides for unconditional recognition of the supremacy of the Constitution and the laws of the Republic of Uzbekistan in the Republic of Uzbekistan and the state, its bodies, officials, public

\footnotetext{
3 Утемуратов М. Ўзбекистон такибида Қорқалпоғистон
}

associations, citizens acting in accordance with the Constitution and laws.

According to this article, since the Republic of Karakalpakstan is an integral part of the Republic of Uzbekistan, the Constitution and laws of the Republic of Uzbekistan are also binding on Karakalpakstan.

This is enshrined in Article 71. It's natural. One of the requirements of the rule of law is that its Constitution and laws govern all spheres of public life.

The Republic of Karakalpakstan unequivocally recognizes the supremacy of the Constitution of the Republic of Uzbekistan. This is reflected in the Rules and Articles of the Constitution of the Republic of Karakalpakstan in accordance with the Constitution and laws of the Republic of Uzbekistan. The same requirement applies to the agreements and treaties of the Republic of Karakalpakstan with other States.

In both republics, a unified legal system and the application of the law require the same laws, based on the rule of law of the Republic of Uzbekistan. Recognition of the supremacy of Uzbekistan's Constitution and laws in Karakalpakstan is also reflected in the fact that the Constitution and laws of Uzbekistan play a leading role in the republican joint work. In a number of areas of law, uniform national laws are directly applied in Karakalpakstan.

The requirement that the Constitution and the laws of the Republic of Karakalpakstan comply with the Constitution of the Republic of Uzbekistan stem from the specifics of the state-legal relations between Uzbekistan and

топишининг назарий, тарихий, сиёсий-ғоявий асослари. - Тошкент, 2005. - Б. 36. 
Karakalpakstan, the constitutional and legal status of Karakalpakstan.

Based on the above considerations, it can be said that the legal system of the Republic of Karakalpakstan is an internal law of Karakalpakstan, part of Uzbekistan, directly related to the history, economic and political system of the state, including law and legislation, which are the main components of the national legal culture. structure and organization of integrity, territorial, functional, genetic and other relationships covering practice and legal ideology, a specific method of governance and mutual regulation, has characteristics of applicability and is an ever-evolving social and legal reality.

Since the legal system of the Republic of Karakalpakstan is an integral part of the legal system of the Republic of Uzbekistan, the basic elements of the legal system are almost identical.

In conclusion, the process of forming a legal system takes a long time. When it is formed as a separate legal system, all elements of the legal system are formed. The basic elements of the legal system are a condition of the legal system. If one of the existing elements of the legal system did not exist, it could not be regarded as a legal system. The legal system of the Republic of Karakalpakstan is an integral part of the legal system of the Republic of Uzbekistan, and these legal systems are constantly interconnected.

\section{REFERENCES}

1. Ўзбекистон Республикаси Конституцияси. Т. «Ўзбекистон», 2019 й
2. Давлат ва хуқуқ назарияси: Дарслик. / Масъул мухаррирлар Х.Б.Бобоев ва Х.Т.Одилқориев. - Тошкент: Иқтисодиёт ва хуқуқ дунёси, 2000.

3. Саидов А., Тожихонов У. Давлат ва хуқуқ назарияси. Икки жилдли. 2-жилд. Хуқуқ назарияси. - Тошкент: Адолат, 2001.

4. Утемуратов М. Ўзбекистон такибида Қорқалпоғистон Республикаси ташкил топишининг назарий, тарихий, сиёсийғоявий асослари. - Тошкент, 2005.

5. Конституциявий хуқуқ. Энциклопедик луғат. / Масъул мухаррир Б.Мустафоев. Тошкент: Ўзбекистон, 2006. 